\title{
PENERAPAN METODE TANGGA MELALUI MEDIA KONKRIT PADA MATERI KPK DAN FPB DALAM MENINGKATKAN HASIL BELAJAR PESERTA DIDIK KELAS 4B SD MUHAMMADIYAH 01 DEPOK
}

\author{
Nama : Idatul Fitri \\ Nim: 836402063 \\ Alamat Email : Idatulfitri4@Gmail.Com
}

\begin{abstract}
ABSTRAK
Penelitian ini adalah penelitian tindakan kelas (PTK) yang dilaksanakan pada peserta didik SD Muhammadiyah 01 Depok yang berjumlah 30, terdiri dari lakilaki 14 orang dan perempuan 16 orang. . penelitian ini bertujuan umtuk meningkatkan hasil belajar peserta didik kelas IV B SD Muhammadiyah 01 Depok dengan metode pembelajaran tangga dan media konkrit. Dari hasil pada pembelajaran prasiklus dengan KKM 70 diperoleh rerata kelas 57,5. Peserta didik yang tuntas hanya $12(40 \%)$ dan dapat menjawab $3(10 \%)$ sedangkan yang tidak dapat menjawab ada 27 (90\%). Pada siklus 1 hasil rata-rata adalah 65. Yang tuntas sebanyak 17 orang (57\%) dan hasil pengamatan hanya $19(63 \%)$ dapat menjawab sedangkan yang tidak dapat menjawab ada 11 (37\%). Pada siklus 2 nilai rata-rata kelas kelas sebesar. Peserta didik yang tuntas dalam belajar sebanyak 27 (90\%), sedangkan hasil pengamatan didapat $28(93 \%)$ yang dapat menjawab dan yang tidak dapat menjawab ada $2(7 \%)$. Dengan demikian pembelajaran menggunakan metode tangga dengan media konkrit pada materi KPK dan FPB dalam meningkatkan hasil belajar peserta didik kelas IV B SD Muhammadiyah 01 Depok dapat meningkatkan hasil belajar, keaktifan serta motivasi bagi peserta didik, materi yang disampaikan oleh guru dapat dimengerti oleh peserta didik. tanggung jawab peserta didik terhadap tugas cukup tinggi, serta membantu peserta didik untuk terlibat aktif didalam kegiatan pembelajaran.
\end{abstract}

Kata-kata kunci: Matematika, KPK dan FPB, dan Metode Tangga.

\section{PENDAHULUAN}

\section{A. Latar Belakang Masalah}

Belajar adalah suatu proses yang kompleks yang terjadi pada diri setiap orang sepanjang hidupnya. Keberhasilan proses belajar didukung oleh kemampuan pengajar dalam membangkitkan minat peserta didik dengan melakukan berbagai strategi pembelajaran yang efektif.

Pembelajaran matematika yaitu kegiatan belajar mengajar yang mempelajari ilmu matematika dengan tujuan membangun pengetahuan matematika agar bermanfaat dan mampu mempraktekkan hasil belajar matematika dalam kehidupan sehari-hari. Selain interaksi yang baik antar guru dan peserta didik tersebut, faktor lain yang menentukan keberhasilan 
pembelajaran matematika adalah bahan ajar yang digunakan dalam proses pembelajaran tersebut.

Rendahnya hasil belajar peserta didik dapat disebabkan karena pendekatan pembelajaran yang digunakan oleh guru dalam proses pembelajaran kurang varitatif. Perlu adanya metode pembelajaran yang tepat dengan disertai penggunaan media bantu pembelajaran yang dapat meningkatkan motivasi belajar yang pada akhirnya diharapkan dapat meningkatkan hasil belajar peserta diidik sesuai dengan yang diharapkan. Oleh karena itu pembelajaran yang tradisional dan konvensional hendaklah mulai ditinggalkan menuju pembelajaran yang menuntut keaktifan peserta didik.

Berdasarkan hasil observasi pra siklus pada peserta didik kelas IV B di SD Muhammadiyah 01 Depok tentang pembelajaran matematika materi KPK dan FPB dengan menggunakan metode ceramah, Tanya jawab dan pemberian tugas, ternyata belum efektif dalam arti sebagian besar peserta didik nilainya masih di bawah kriteria ketuntasan minimal (KKM) yang ditetapkan yaitu $\geq 70$. Hasil pada mata pelajaran matematika materi KPK dan FPB diperoleh nilai terendah 25, nilai tertinggi 100 dan nilai ratarata 57,5. Dari 30 peserta didik yang mencapai KKM hanya 12 peserta didik. Rendahnya hasil belajar matematika disebabkan oleh beberapa faktor diantaranya metode yang kurang tepat dan kurang menarik. Oleh karena itu diperlukan suatu solusi dengan menggunakan metode pembelajaran yang tepat.

Setelah mengkaji permasalahan pada pembelajaran menulis laporan dan juga berdiskusi dengan kolabolator yaitu dengan teman sejawat SD Muhammadiyah 01 Depok, sepakat akan dilakukan perbaikan pembelajaran yaitu dengan menerapkan metode tangga dengan menggunakan media konkrit. Salah satu fungsi media pembelajaran adalah membuat konkret konsep-konsep yang abstrak. Konsep-konsep yang dirasakan masih bersifat abstrak dan sulit dijelaskan secara langsung kepada peserta didik bisa 
dikonkretkan atau disederhanakan melalui pemanfaatan media pembelajaran.

Berdasarkan uraian di atas maka penulis tergerak untuk melakukan penelitian tindakan kelas dengan judul : "Penerapan Metode Tangga Melalui Media Konkrit Pada Materi KPK dan FPB Dalam Meningkatkan Hasil Belajar Peserta Didik Kelas 4b SD Muhammadiyah 01 Depok".

\section{Identifikasi Masalah}

Berdasarkan latar belakang masalah yang telah dikemukakan diatas, dapat diidentifikasi masalah-masalah sebagai berikut:

a. Rendahnya hasil belajar peserta didik pada mata pelajaran matematika yang dibawah KKM.

b. Peserta didik cenderung bersikap pasif dalam mengikuti kegiatan pembelajaran.

c. Ketidaksesuaian penggunaan strategi dan metode dengan materi yang akan dipelajari.

d. Media pembelajaran yang digunakan guru kurang menarik.

e. Pendekatan dalam pembelajaran masih terlalu didominasi oleh guru (teacher centered).

\section{Analisis Masalah}

Berdasarkan identifikasi masalah di atas, dapat ditemukan penyebab rendahnya hasil belajar peserta didik kelas IV B dalam pelajaran Matematika materi KPK dan FPB di SD Muhammadiyah 01 Depok adalah:

a. Penjelasan materi kurang menarik. Penggunaan ceramah dan tanya jawab mengakibatkan peserta didik kesulitan dalam memberikan gambaran dalam ranah pemahamannya mengenai KPK dan FPB.

b. Dominasi guru sehingga peserta didik cendrung pasif dalam belajar mengakibatkan peserta didik yang mengalami kesulitan belajar cendrung tidak dapat memahami materi dengan baik. 
c. Tidak adanya media/alat bantu pembelajaran sehingga pesrta didik menjadi jenuh dengan materi yang diajarkan.

d. Pembelajaran masih bersifat individual sehingga tingkat keberhasilan atau ketuntasan secara klasikal sangat rendah. Pembelajaran konvensional mengakibatkan setiap individu peserta didik bekerja dan bertanggung jawab terhadap hasil pekerjaannya sendiri, sehingga bagi peserta didik yang belum memahami akan kesulitan untuk menyelesaikan tugasnya karena tidak adanya wadah berupa tugas atau bentuk kerjasama yang memungkinkan terjadinya pertukaran ide, gagasan, atau pengetahuan di antara sesama peserta didik.

e. Guru menggunakan alternatif media pembelajaran atau alat peraga untuk menarik minat belajar peserta didik.

\section{Alternatif dan Prioritas Pemecahan Masalah}

Berdasarkan identifikasi masalah, penulis memprioritaskan alternatif pemecahan masalah sebagai berikut:

a. Guru mencari alternatif metode pembelajaran untuk mengatasi kekurangan yang diakibatkan oleh pembelajaran konvensional yang dilaksanakan oleh guru. Metodde yang diharapkan oleh guru untuk mengatasi yang masalah rendahnya nilai peserta didik adalah dengan menerapkan metode tangga.

b. Rendahnya peran serta peserta didik diharapkan dapat diatasi dengan pembelajaran kooperatif dengan menggunakan metode tangga serta penggunaan media konkret

c. Pembelajaran kooperatif yang melibatkan peserta didik secara aktif ditujukan untuk mengatasi masalah yang timbul akibat dominasi guru yang turut menjadi masalah akan rendahnya hasil belajar yang diperoleh oleh peserta didik

d. Tugas kelompok sebagai cara bagi peserta didik untuk memahami materi dirancang dengan melibatkan keikutsertaan aktif peserta didik. Hal ini dimaksudkan agar peserta didik yang belum memahami dapat memahami 
materi melalui rangkaian penugasan yang dilakukannya melalui kerjasama dalam kelompoknya masing-masing.

\section{B. Rumusan Masalah}

Berdasarkan latar belakang, identifikasi masalah dan pembatasan masalah diatas, maka dapat disusun perumusan masalah, yaitu Bagaimana penerapan metode tangga melalui media konkrit pada materi KPK dan FPB dalam meningkatkan hasil belajar peserta didik kelas 4B SD Muhammadiyah 01 Depok?

\section{Tujuan Penelitian Perbaikan Pembelajaran}

Berdasarkan latar belakang dan rumusan masalah di atas maka tujuan perbaikan ini adalah menemukan cara yang tepat untuk meningkatkan hasil belajar peseta didik pada mata pelajaran matematika tentang KPK dan FBP, pada kelas IV B SD Muhammadiyah 01 Depok.

\section{Manfaat Penelitian Perbaikan Pembelajaran}

Hasil penelitian perbaikan pembelajaran ini diharapkan dapat memberikan manfaat sebagai berikut:

1. Manfaat secara teoritis

a. Memberikan masukan kepada guru dan caon guru terhadap ranah pendidikan dalam upaya meningkatkan hasil belajar peserta didik.

b. Sebagai masukan bagi sekolah dalam mengembangkan penerapan metode tangga untuk pembelajaran-pembelajaran pada mata pelajaran yang lain.

2. Manfaat secara praktis

a. Dapat digunakan sebagai refrensi bagi studi kasus yang sejenis yang melibatkan pembelajaran Matematika dengan penerapan metode tangga.

b. Masukan bagi peneliti yang lain yang bermaksud melakukan penelitian lebih lanjut. 


\section{KAJIAN PUSTAKA}

\section{A. Hasil Belajar Matematika}

\section{Hasil Belajar}

Menurut Anita (2017: 1.17) Hasil belajar adalah berupa perubahan prilaku, baik yang menyangkut kognitif, psikomotorik, maupun afektif. Dari masing-masing ranah mempunyai aspek yang berkaitan. Diantaranya ketiga ranah itu, ranah kognitiflah yang paling banyak dinilai oleh para guru disekolah karena berkaitan dengan kemampuan para peserta didik dalam menguasai isi bahan pengajaran. Sedangkan menurut Sudjana (2004: 22) hasil belajar adalah kemampuan-kemapuan yang dimiliki peserta didik setelah menerima pengalaman belajarnya. Dan menurut Sanjaya (2008: 13) hasil belajar adalah hasil yang berkaitan dengan pencapaian siswa dalam memperoleh kemampuan atau kemampuan menguasai materi pelajaran sesuai dengan tujuan khusus yang direncanakan.

Hasil belajar dikemukakan oleh beberapa faktor antara lain adalah tujuan, guru, anak didik, kegiatan pengajaran, alat evaluasi, bahan evaluasi, dan sasaran evaluasi. (Djamarah dan Zain, 2010: 109). Menurut Hamalik (2011: 157) bahwa pengukuran atau evaluasi hasil belajar adalah keseluruhan kegiatan pengukuran (pengumpulan data dan informasi), pengolahan, penafsiran dan pertimbangan untuk membuat keputusan tentang tingkat hasil belajar yang dicapai oleh peserta didik setelah melakukan kegiatan belajar dalam upaya mencapai tujuan pembelajaran yang telah ditetapkan.

Berdasarkan paparan para ahli di atas, dapat disimpulkan bahwa hasil belajar merupakan perubahan perilaku secara menyeluruh bukan hanya pada satu aspek saja tetapi terpadu secara utuh. Untuk memperoleh perwujudan hasil belajar akan selalu berkaitan dengan kegiatan evaluasi pembelajaran sehingga diperlukan adanya tehnik dan peosedur evaluasi belajar yang dapat menilai secara efektif proses dan hasil belajar.

\section{Hakikat Mata Pelajaran Matematika}

Mata pelajaran matematika mempunyai beberapa definisi antara lain adalah Suwangsih dan Tiurlina: (2010: 3) kata mathematike berasal dari 
kata mathema yang memiliki arti pengetahuan atau ilmu (knowledge, science). Selain itu, kata mathematike berhubungan juga dengan kata lain yang hampir sama, yaitu mathein dan mathenein yang berarti berpikir. Sedangkan menurut Muhsetyo (2008: 26) mengatakan pembelajaran matematika adalah proses pemberian pengalaman belajar kepada peserta didik melalui serangkaian kegiatan yang terencana sehingga peserta didik memperoleh kompetensi tentang bahan matematika yang dipelajari.

Menurut Rahayu (2007: 2) hakikat pembelajaran matematika adalah proses yang sengaja dirancang dengan tujuan untuk menciptakan suasana lingkungan yang memungkinkan seseorang melaksanakan kegiatan belajar matematika dan pembelajaran matematika harus memberikan peluang kepada peserta didik untuk berusaha dan mencari pengalaman tentang matematika. Melalui penggunanaan abstraksi dan penalaran logika, matematika dikembangkan dari pencahan, penghitungan, dan pengkajian sistemaik terhadap bentuk dan gerak objek-objek fisika. Pengetahuan dan penggunaan matematika dasar selalu menjadi sifat melekat dan bagian utuh dari kehidupan individual dan kelompok.

Berdasarkan uraian di atas, dapat disimpulkan bahwa pembelajaran matematika yaitu kegiatan belajar mengajar yang mempelajari ilmu matematika dengan tujuan membangun pengetahuan matematika agar bermanfaat dan mampu mempraktekkan hasil belajar matematika dalam kehidupan sehari-hari. Dan hasil belajar matematika adalah kemampuan yang dimiliki peserta didik terhadap pelajaran matematika yang diperoleh dari pengalaman-pengalaman dan latihan-latihan selama proses belajar mengajar yang menggambarkan penguasaan peserta didik terhadap materi pelajaran matematika yang dapat dilihat dari nilai matematika dan kemampuannya dalam memecahkan masalah-masalah matematika.

\section{B. Metode Tangga}

Menurut Hartono (2013: 44) metode adalah cara yang dapat digunakan untuk melaksanakan strategi. Metode tangga memiliki penyelesaian cukup cepat untuk mempersingkat waktu pengerjaan. 
Penggunaan metode tangga memungkinkan peserta didik dapat mengelompokkan faktor-faktor yang merupakan Faktor Persekutuan Terbesar (FPB) dan Kelipatan Persekutuan Terkecil (KPK) sehingga dapat menimbulkan kepercayaan diri peserta didik. Penerapan metode tangga, yaitu dengan cara menghitung dengan menggunakan susunan tangga lalu dibagi dengan bilangan prima yang terkecil dan seterusnya, membagikannya sampai tidak bisa dibagi lagi dengan bilangan prima lagi. Lalu cara menghitung FPB dengan membuat garis vertikal dan cara menghitung KPK dengan cara membuat garis vertikal dan horizontal lalu dikalikan untuk menghitungnya.

Penerapan metode tangga yang disertai dengan penggunaan alat peraga sebagai media konkret yang berguna untuk pembuktian hasil perhitungan yang dilakukan peserta didik dapat memudahkan pemahaman peserta didik terhadap KPK dan FPB dari bilangan-bilangan yang terkait. Peserta didik dapat mencoba sendiri membuktikan hasil pekerjaannya setelah guru memberikan contoh penggunaannya dengan demikian diharapkan proses pembelajaran dapat dilaksanakan dengan santai dalam suasana yang menyenangkan tetapi peserta didik tetap fokus terhadap materi yang dipelajarinya. Proses pembelajaran yang dilakukan ini diharapkan dapat menimbulkan dan meningkatkan tingkat kreatifitas peserta didik dan keaktifan peserta didik dalam mengikuti pembelajaran.

Walaupun demikian metode tangga bukan tanpa kekurangan, metode ini mengalami kesulitan serupa dengan metode tabel yang membutuhkan proses yang cukup panjang apabila melibatkan angka yang relatif besar. Namun demikian penggunaan metode ini dapat meminimalisir kesalahan penghitungan yang dilakukan oleh peserta didik.

Mengingat lebih banyak keuntungan menerapkan metode tangga dibandingkan dengan kekurangannya, maka penulis memutuskan untuk menerapkan metode tangga dalam pemecahan masalah rendahnya hasil belajar siswa pada mata pelajaran matematika materi KPK dan FPB.

Berikut ini adalah cara-cara penggunaan metode tangga: 
1. Bagi semua bilangan dengan bilangan prima yang sama. Bilangan prima kurang dari 20 ialah 2, 3, 5, 7, 11, dan 17 (jika semua bilangan tidak bisa dibagi 2, maka diganti dengan 3, dan seterusnya)

2. Lakukan langkah di atas hingga semua bilangan tidak bisa lagi dibagi dengan bilang prima yang sama. Hentikan operasinya, lalu kalikan semua pembaginya. Hasil perkalian itulah yang merupakan FPB

3. Kalikan semua bilangan prima pada kolom baris dan baris agar mendapatkan hasil yang merupakan KPK dari bilangan yang dicari.

Berdasarkan uraian di atas, dapat disimpulkan bahwa metode tangga yaitu metode pembelajaran yang menghitung menggunakan susunan tangga lalu dibagi dengan bilangan prima yang terkecil dan seterusnya. Dan cara menghitungnya dengan membuat garis vertikal dan horizontal lalu dikalikan untuk menghitungnya

\section{Media Konkret}

Menurut Hermawan, Resmini dan Andayani (2017: 2.24) media pembelajaran merupakan salah satu komponen pembelajaran yang berkaitan dengan komponen lainnya dalam pembelajaran dalam rangka membantu peserta didik belajar. Tanpa media pembelajaran yang bervariasi maka kegiatan inti pembelajaran terpadu tidak akan berjalan dengan efektif. Dengan menggunakan media pembelajaran, kita dapat memanfaatkan nilai yang terkandung dalam media pembelajaran untuk memfasilitasi terjadinya proses belajar pada diri peserta didik. Menurut Dale bahwa pengalaman langsung mendapat tempat utama dan terbesar sedangkan belajar melalui abstrak berada di puncak kerucut (Munadi, 20012: 19). Konkret berarti nyata dapat dibuktikan dalam pengertiannya. Seperti yang diungkapkan Jennah (2009: 79) bahwa objek adalah "benda sebenarnya yang dapat dijadikan sebagai media pembelajaran" media konkret perlu digunakan untuk mempermudah peserta didik didalam proses pembelajaran untuk mencapai tujuan pengajaran. Sedangkan menurut Ibrahim dan Syaodih (2003: 118), yang dimaksud media konkret adalah "untuk mencapai hasil yang optimal dari proses belajar mengajar salah satu yang disarankan dalam 
digunakannya pula media yang bersifat langsung, bersifat nyata atau realita". Benda konkret yang sesungguhnya akan memberikan ransangan yang amat penting bagi peserta didik dalam mempelajari berbagai hal, terutama yang menyangkut pengembangan keterampilan tertentu. Melalui penggunaan media konkret ini, kegiatan belajar mengajar dapat melibatkan semua indera peserta didik, terutama indera peraba.

Mulyani Sumantri, (2004: 178) mengemukakan bahwa secara umum media konkret berfungsi sebagai:

1. Alat bantu untuk mewujudkan situasi belajar mengajar yang efektif,

2. Bagian integral dari keseluruhan situasi mengajar,

3. Meletakkan dasar-dasar yang konkret dan konsep yang abstrak sehingga dapat mengurangi pemahaman yang bersifat verbalisme,

4. Mengembangkan motivasi belajar peserta didik,

5. Mempertinggi mutu belajar mengajar.

Berdasarkan uraian para ahli di atas, dapat disimpulkan bahwa media konkret adalah media atau benda yang digunakan pendidik pada saat proses belajar mengajar di kelas yang dapat dilihat secara langsung dan nyata oleh peserta didik. media konkret juga ini berasal dari benda-benda yang mudah didapatkan dan mudah digunakan sehingga membantu memudahkan peserta didik memahami suatu pelajaran yang disampaikan pendidik, karena itu media konkret sangat berperan dalam proses belajar mengajar.

\section{Penelitian Tindakan Kelas}

Menurut Wardhani dan Kuswaya (2017: 1.15) bahwa peneitian tindakan kelas adalah refleksi diri, dengan tujuan untuk memperbaiki kinerjanya sebagai guru, sehingga hasil belajar peserta didik menjadi meningkat. Karakteristik penelitian tindakan kelas antara lain:

1. An inquiry of practice from within (penelitian berawal dari keseriusan guru akan kinerjanya).

2. Self-reflective inquiry (metode utama adalah refleksi diri, bersifat agak longgar, tetapi tetap mengikuti kaidah-kaidah penelitian. 
3. Fokus penelitian berupa kegiatan pembelajaran.

4. Tujuannya memperbaiki pembelajaran.

Penelitian tindakan kelas bermanfaat bagi guru, pembelajar/peserta didik, serta bagi sekolah. Manfaat PTK bagi guru adalah sebagai berikut.

1. Membantu guru memperbaiki pembelajaran.

2. Membantu guru berkembang secara professional.

3. Meningkatkan rasa percaya diri guru.

4. Memungkinkan guru secara aktif mengembangkan pengetahuan dan keterampilan.

Bagi pembelajaran/ peserta didik, PTK bermanfaat untuk meningkatkan proses/hasil belajar peserta didik, di samping guru yang melaksanakan PTK dapat menjadi model bagi para peserta didik dalam bersikap kritis terhadap hasil belajarnya. Bagi sekolah, PTK membantu sekolah untuk berkembang karena adanya peningkatan/kemajuan pada diri guru dan pendidikan di sekolah tersebut. Di samping manfaat, PTK mempunyai keterbatasan, yaitu validitasnya yang sering masih dipertanyakan, serta tidak mungkin melakukan generalisasi karena sampelnya hanya kelas dari guru yang berperan sebagai pengajar dan peneliti.

\section{PELAKSANAAN PENELITIAN PERBAIKAN PEMBELAJARAN}

\section{A. Subjek, Tempat, Waktu Penelitian, dan Pihak yang Membantu}

1. Subjek Penelitian

Dalam Penelitian Tindakan Kelas ini yang menjadi subjek penelitian adalah peserta didik kelas IV B SD Muhammadiyah 01 Depok sebanyak 30 orang terdiri dari laki-laki 14 orang dan perempuan 16 orang. Alasan peneliti melaksanakan perbaikan pembelajaran di kelas ini karena peserta didik pada umumnya tidak suka dengan pelajaran matematika, sehingga pada setiap evaluasi dilaksanakan hasilnya selalu rendah. Hal inilah yang menjadi motivasi untuk dikalsanakan penelitian dengan harapan menemukan langkah-langkah pembelajaran yang dapat meningkatkan hasil belajar siswa. 
2. Tempat Penelitian

Sekolah yang dijadikan tempat penelitian adalah SD Muhammadiyah 01 Depok, tempat peneliti bertugas dengan harapan dapat memperbaiki dan meningkatkan aktivitas proses belajar mengajar.

3. Waktu Penelitian

Penelitian Tindakan Kelas dilaksanakan mulai tanggal 27 Juli 2018, dari pukul 09.40-10.50. lalu lanjut siklus 1 tanggal 3 Agustus 2018, dari pukul 09.40-10.50 dan berakhir di siklus 2 tanggal 10 Agustus 2018, dari pukul 09.40-10.50.

4. Pihak yang membantu

Peneliti dibantu oleh Kepala Sekolah Elya S.Pd, dan teman sejawat Arif Azwar Anas, S.Pd.

\section{B. Disain Prosedur Perbaikan Pembelajaran}

1. Siklus 1

a. Perencanaan

1) Membuat RPP dengan menggunakan metode tangga, kooperatif, dan tanya jawab

2) Membuat lembar kerja kelompok

3) Menyiapkan lembar evaluasi peserta didik

b. Pelaksanaan

1) Kegiatan Awal (10 menit)

a) Guru mengajak peserta didik berdo'a, mengisi daftar kelas, menulis hari dan tanggal di papan tulis dan mempersiapkan materi ajar.

b) Guru memberikan motivasi belajar kepada para peserta didik melalui "tepuk semangat"

c) Guru melakukan kegiatan apersepsi dengan memberikan pertanyaan yang berhubungan dengan materi. Contoh: masih ingatkah kalian dengan materi pelajaran pada pertemuan sebelumnya? Dapatkah kalian menggunakan apa yang telah kalian pahami dalam kehidupan sehari-hari 
d) Dari jawaban peserta didik guru kemudian mengaitkannya dengan tujuan pembelajaran.

e) Guru menyampaikan tujuan pembelajaran setelah pembelajaran peserta didik dapat menyebutkan Materi KPK dan FPB dari dua bilangan.

f) Guru menyampaikan topik yang akan dipelajari yaitu Materi KPK dan FPB dari dua bilangan.

2) Kegiatan inti ( \pm 25 menit)

a) Eksplorasi

- Guru menjelaskan materi pembelajaran Matematika Tentang Materi KPK dan FPB dari dua bilangan dengan menggunakan metode tangga

- Guru memberikan contoh menyelesaikan beberapa masalah dengan menggunakan metode tangga

- Peserta didik memperhatikan penjelasan guru tentang materi dan menjawab pertanyaan guru

b) Elaborasi

- Peserta didik diberikan kesempatan bertanya apabila ada hal yang belum dipahami baik tentang materi maupun tentang tata cara kerja kelompok.

- Guru membagi peserta didik dalam kelompok kecil yang heterogen (terdiri dari 4-5 orang)

- Guru membagikan Lembar Kerja Kelompok kepada masingmasing peserta didik.

- Sebelum peserta didik bekerja dalam kelompoknya, guru mengingatkan kembali bagaimana cara bekerja yang baik di dalam kelompok

- Peserta didik diberikan kesempatan untuk menyelesaikan tugas Lembar Kerja Kelompoknya 
- Selama kegiatan berlangsung, guru berperan sebagai fasilitator untuk memberikan bantuan kepada peserta didik apabila peserta didik mengalami kesulitan.

- Setelah mengerjakan tugas, guru memanggil perwakilan kelompok untuk menuliskan hasil pekerjaannya di depan kelas.

- Kelompok yang lain diminta untuk memberikan tanggapan terhadap hasil kerja temannya.

- Peserta didik dan guru memberikan apresiasi terhadap hasil kerja kelompok yang telah dilaksanakan.

c) Konfirmasi

- Setelah proses kerja kelompok selesai, siswa diberikan kesempatan bertanya apabila masih ada hal yang belum dipahami berkaitan dengan penyelesaian KPK dan FPB dengan menggunakan metode tangga

- Peserta didik dengan dibantu oleh guru, menyusun kesimpulan atas proses pembelajaran yang telah dijalaninya

3) Kegiatan akhir ( \pm 15 menit)

a) Guru memberikan evaluasi sebagai alat ukur dari proses pembelajaran yang dilaksanakan.

b) Peserta didik mengumpulkan evaluasi yang telah dilaksanakan.

c) Guru menutup pembelajaran dengan memberikan kesan dan pesan yang baik.

c. Pengamatan

Berdasarkan pengamatan, ditemukan beberapa hal yang menjadi permasalahan yaitu: peserta didik tidak dapat menjawab pertanyaan sehingga hasilnya pun kurang memuaskan tidak sesuai dengan KKM yang diinginkan:

1) Media pembelajaran yang digunakan guru kurang menarik, bervariasi dan efektif sehingga peserta didik mengalami kesulitan. 
2) Rendahnya hasil belajar peserta didik pada mata pelajaran matematika yang dibawah KKM.

d. Refleksi

1) Kekuatan

Peserta didik mulai antusias terhadap metode yang digunakan

2) Kelemahan

Kurangnya media dalam pembelajaran siklus 1

2. Siklus 2

a. Perencanaan

Peneliti membuat rencana perbaikan pembelajaran berdasarkan refleksi siklus 2 untuk mencapai tujuan pembelajaran yang lebih baik. Hal-hal yang dipersiapkan adalah menyusun perangkat pembelajaran yang lebih lengkap sesuai dengan tujuan yang ingin dicapai, dan membuat lembar observasi untuk mengamati partisipasi aktif peserta didik dalam pembelajaran.

b. Pelaksanaan

1) Kegiatan Awal (10 menit)

a) Peserta didik berdo'a dengan bimbingan guru lalu, guru mengisi daftar kelas, menulis hari dan tanggal di papan tulis dan mempersiapkan materi ajar.

b) Peserta didik diberikan motivasi belajar melalui "tepuk semangat" oleh guru.

c) Peserta didik diberikan apersepsi oleh guru dengan memberikan pertanyaan yang berhubungan dengan materi. Contoh: pernahkah kalian memiliki permen, coklat dan harus dibagi sama banyak dengan saudara kalian?

d) Dari jawaban peserta didik guru kemudian mengaitkannya dengan tujuan pembelajaran.

e) Guru menyampaikan tujuan pembelajaran setelah pembelajaran peserta didik dapat menyebutkan Materi KPK dan FPB dari dua bilangan. 
f) Guru menyampaikan topik yang akan dipelajari yaitu Materi KPK dan FPB dari dua bilangan

2) Kegiatan inti ( \pm 25 menit $)$

a) Eksplorasi

- Peserta didik memperhatikan penjelasan guru mengenai materi pembelajaran Matematika Tentang Materi KPK dan FPB dari dua bilangan dengan metode tangga menggunakan alat peraga gelas aqua dan biji-bijian.

- Peserta didik diberikan contoh oleh guru untuk menyelesaikan beberapa masalah dengan metode tangga menggunakan alat peraga gelas aqua dan biji-bijian.

- Peserta didik memperhatikan penjelasan guru tentang materi dan menjawab pertanyaan guru

b) Elaborasi

- Guru memanggil perwakilan peserta didik untuk menyelesaikan masalah tentang KPK dan FPB dengan metode tangga menggunakan alat peraga gelas aqua dan biji-bijian peserta didik yang lain diminta untuk memperhatikan dan memberikan masukan kepada proses kerja dari peserta didik yang bertindak selaku perwakilan mereka.

- Peserta didik diminta memberikan tanggapan terhadap hasil kerja temannya.

- Guru membagi peserta didik dalam kelompok kecil yang heterogen (terdiri dari 4-5 orang).

- Guru membagikan Lembar Kerja Kelompok dan alat peraga gelas aqua dan biji-bijian untuk memecahkan masalah.

- Peserta didik mengerjakan Lembar Kerja Kelompok untuk memecahkan masalaah dengan bimbingan guru.

- Peserta didik diberi kesempatan untuk bertanya apabila ada yang belum jelas mengenai materi KPK dan FPB. 
- Setelah mengerjakan tugas, guru memanggil perwakilan kelompok untuk mempresentasikan hasil Lembar Kerja Kelompoknya di depan kelas.

- Kelompok yang lain diminta untuk memberikan tanggapan terhadap hasil kerja temannya.

- Peserta didik dan guru memberikan apresiasi terhadap kelompok yang mempresentasikan hasil kerja kelompok di depan kelas.

c) Konfirmasi

- Peserta didik diberikan kesempatan bertanya oleh guru tentang materi yang telah dipelajari dari keseluruhan proses yang telah dilaksanakan.

- Peserta didik menyimpulkan materi pembelajaran dengan bimbingan guru.

3) Kegiatan akhir ( \pm 15 menit)

a) Peserta didik diberikan evaluasi oleh guru sebagai alat ukur dari proses pembelajaran yang dilaksanakan.

b) Peserta didik mengumpulkan evaluasi yang telah dilaksanakan.

c) Guru menutup pembelajaran dengan memberikan kesan dan pesan yang baik.

c. Pengamatan

Peneliti melakukan pengamatan terhadap aktivitas peserta didik dalam mengikuti perbaikan pembelajaran dengan metode tangga dan menggunakan media konkrit. Hasil penelitian ternyata hasil belajar peserta didik kelas IV B pada materi KPK dan FPB meningkat dengan nilai rata-rata 88 dan meningkatnya motivasi serta semangat pesrta didik dalam rasa kebersamaan.

d. Refleksi

Hasil peneliti melakukan refleksi pada pelaksanaan siklus 2 untuk bahan tindak lanjut aktivitas pembelajaran dimana peneliti bertugas dan akan dijadikan saran bagi peneliti-peneliti lain yang akan melakukan Penelitian Tindakan Kelas. Selain itu untuk melihat hasil 
perbaikan pembelajaran pada siklus 2 , ternyata nilai hasil belajar peserta didik mencapai rata-rata 88, itu artinya nilai rata-rata sudah di atas KKM, dengan hasil ini maka penulis tidak meneruskan lagi siklus berikutnya.

\section{Teknik Analisi Data}

Hasil data diperoleh pada setiap kegiatan penelitian dari pelaksanaan siklus penelitian dianalisis secara deskriptif dengan menggunakan tehnik presentase untuk melihat hasil yang terjadi dalam kegiatan pembelajaran mata pelajaran matematika. Dalam penelitian ini dibutuhkan dua siklus perbaikan untuk mata pelajaran matematika. Pada waktu perbaikan pembelajaran yang peneliti lakukan melalui tiga tahapan, diantaranya adalah perencanaan, pelaksanaan, pengamatan dan refleksi.

Teknik pengumpulan data dilakukan dengan ter tertulis, yaitu:

1. Pada prasiklus bentuk isian singkat sebanyak 4 soal, siklus 1 bentuk isian singkat sebanyak 4 soal dan siklus 2 Bentuk isian singkat sebanyak 5 soal Dengan skor $\frac{\text { Jumlah Jawaban Benar }}{\text { Jumlah Soal }} \times 100=$ nilai peserta didik

2. Pada prasiklus peneliti melakukan diskusi dengan teman sejawat tentang keberhasilan dan kekurangn atau kelemahan dalam prasiklus dengan pelaksanaan pembelajaran melalui metode ceramah.

3. Pada siklus 1 peneliti melakukan diskusi dengan teman sejaawat tentang keberhasilan dan kekurangan atau kelemahan dalam siklus 1 dengan pelaksanaan pembelajaraan metode tangga

4. Pada siklus 2 peneliti melakukan diskusi dengan teman sejawat tentang keberhasilan dan kekurangan atau kelemahan dalam pelaksanaan pembelajaran melalui metode tangga menggunakan media konkrit, termasuk merefleksi hasil setiap siklus untuk perbaikan-perbaikan aktivitas dan praktik pembelajaran yang akan datang.

Data yang dikumpulkan pada setiap kegiatan penelitian dari pelaksanaan siklus penelitian dianalisis secara deskriptif dengan 
menggunakan teknik presentase untuk melihat peningkatan yang terjadi dalam kegiatan pembelajaran mata pelajaran matematika.

\section{HASIL DAN PEMBAHASAN}

\section{A. Deskripsi Hasil Penelitian Perbaikan Pembelajaran}

1. Pra Siklus

Berdasarkan hasil kegiatan belajar mengajar yang dilakukan pada Hari Jum'at Tanggal 27 Juli 2018, dengan nilai hasil evaluasi yang diperoleh dari keseluruhan peserta didik 1725, dengan nilai rata-rata KKM 57,5, dengan rincian nilai tertinggi 100 ada 4 peserta didik, salah satunya Amabel Keisha Darmawan, Faiza Hasya Azzahra, Luthfia Hanifah dan Putri Larasati Wibowo, dan yang mendapat nilai 75 ada 8 peserta didik, sedangkan yang mendapat nilai 50 ada 11 peserta didik, dan yang mendapat 25 ada 7 peserta didik, dan 3 diantaranya yaitu Almaira Caesarina Mecca, Aqilla Mirza Fadjriansyah, dan Aqillidin Adi Wibowo.

Nilai hasil evaluasi peserta didik tidak memuaskan, masih ada 18 peserta didik atau $60 \%$ yang di bawah KKM atau tidak tuntas, dan ada 12 peserta didik atau $40 \%$ yang di atas $\mathrm{KKM}$ atau tuntas dari 30 peserta didik yang terdiri dari 14 orang laki-laki dan 16 orang perempuan. Dari pengamatan peneliti terhadap hasil dari 30 peserta didik, hanya 8 peserta didik yang dapat menjawab yaitu 27\%, tiga diantaranya yaitu Akhtar Rahadian, Amabel Keisha Darmawan, dan Faiza Hasya Azzahra sedangkan yang tidak dapat menjawab ada 22 peerta didik yaitu beberapa yang bisa menjawab $73 \%$ yaitu Ilmii Rizqi Zulkarnain, Inaya Azmi Athifa dan Jihan Syifa Salsabila.

Dari data di atas dapat dibuat interval sebagai berikut. Menurut Suryanto (2017: 4.25) cara membuat daftar distribusi frekuensi dapat disusun sebagai berikut.

a. Tentukan rentang, ialah data terbesar di kurang data terkecil. Dalam prasiklus data terbesar adalah 100 dan data terkecil 25, maka rentangnya adalah $100-25=75$ 
b. Tentukan banyak kelas interval yang diperlukan. Untuk menentukan banyaknya kelas interval dapat digunakan aturan sturges yaitu:

$=1+3,3 \log n$

$=1+3,3 \log 30$

$=1+3,3(1,48)$

$=1+4,78$

$=5,78$

Jadi banyaknya kelas interval yang dapat dibulatkan menjadi 6

c. Menentukan panjang kelas interval (p)

$$
\begin{aligned}
P & =\frac{\text { Rentang }}{\text { banyak kelas }} \\
& =75: 6 \\
& =12,5
\end{aligned}
$$

Jadi dari hasil diperoleh 12,5 dibulatkan menjadi 13 sebagai kelas interval.

Dari data di atas dapat diketahui jumlah peserta didik yang berada direntang nilai 25-38 ada 7 peserta didik, 39-52 ada 11 peserta didik, 53-66 tidak ada peserta didik, 67-80 ada 8 peserta didik, 81-94 tidak ada peserta didik, dan 95-100 ada 4 peserta didik.

Dari pengamatan peneliti terhadap hasil dari 30 peserta didik, hanya 8 peserta didik yang dapat menjawab yaitu 27\% sedangkan yang tidak dapat menjawab ada 22 peerta didik yaitu beberapa yang bisa menjawab 73\%. Dengan demikian hasil pra siklus melalui dua tabel di atas peserta didik belum sepenuhnya mencapai KKM 75. Tabel skor menunjukkan jumlah hasil uji kompetensi anak 1725 dengan rat-rata kelas 57,5 nilai tertinggi 100 dan terendah 25, dari presentase hanya 18 peserta didik yang berhasil mencapai KKM. Interval menunjukkan rentang nilai 25-38 ada 7 peserta didik, 39-52 ada 11 peserta didik, 53-66 tidak ada peserta didik, 67-80 ada 8 peserta didik, 81-94 tidak ada peserta didik, dan 95-100 ada 4 peserta didik. 
Dari deskripsi di atas dapat disimpulkan bahwa hasil peserta didik mendapat skor di bawah KKM. Berdasarkan nilai rata-rata dapat disimpulkan bahawa pesrta didik $60 \%$ belum memahami materi. Apabila disajikan dalam bentuk grafik dapat dilihat di bawah ini:

\section{Kegiatan Siklus 1}

Pada tanggal 3 Agustus 2018, peneliti melakukan Perbaikan Pembelajaran Siklus 1. Permasalahan pertama yang diperbaiki adalah bagaimana cara mengajarkan KPK dan FPB. Hal ini bisa dilihat dari ketuntasan belajar yang baru mencapai 57\%. Permasalahan kedua peserta didik kurang tertarik dan termotivasi karena metode yang digunakan hanya ceramah, tanya jawab dan penugasan saja pada prasiklus. Maka pada siklus 1 guru menggunakan metode tangga pada KPK dan FPB yang relevan dengan materi. Sedangkan permasalahan yang ketiga pada siklus 1 masih banyak yang belum dapat menjawab pertanyaanpertanyaan yang diberikan oleh guru.

Dari masalah-masalah di atas peneliti melakukan refleksi dan diskusi dengan teman sejawat untuk mendapatkan masukan hasil pembelajaran yang telah dilaksanakan serta bagaimana upaya yang harus dilakukan agar pada siklus berikutnya lebih meningkat hasil belajarnya. Pada siklus 1 nilai belajar siswa mencapai rata-rata 65 .

Dari data di atas dapat dibuat interval sebagai berikut.

a. Tentukan rentang, ialah data terbesar di kurang data terkecil. Dalam prasiklus data terbesar adalah 100 dan data terkecil 25, maka rentangnya adalah $100-25=75$

b. Tentukan banyak kelas interval yang diperlukan. Untuk menentukan banyaknya kelas interval dapat digunakan aturan sturges yaitu:

$$
\begin{aligned}
& =1+3,3 \log \mathrm{n} \\
& =1+3,3 \log 30 \\
& =1+3,3(1,48) \\
& =1+4,78 \\
& =5,78
\end{aligned}
$$


Jadi banyaknya kelas interval yang dapat dibulatkan menjadi 6

c. Menentukan panjang kelas interval (p)

$$
\begin{aligned}
P & =\frac{\text { Rentang }}{\text { banyak kelas }} \\
& =75: 6 \\
& =12,5
\end{aligned}
$$

Jadi dari hasil diperoleh 12,5 dibulatkan menjadi 13 sebagai kelas interval.

Dari data di atas dapat diketahui jumlah peserta didik yang berada di rentang nilai $25-38$ ada 3 peserta didik, 39-35 ada 10 peserta didik, 53-66 tidak ada peserta didik 67-80 ada 13 peserta didik, 81-94 tidak ada peserta didik dan 95-100 ada 4 peserta didik. Dari pengamatan peneliti terhadap hasil dari 30 peserta didik, hanya 19 peserta didik yang dapat menjawab yaitu $63 \%$ sedangkan yang tidak dapat menjawab ada 11 peerta didik yaitu beberapa yang bisa menjawab $37 \%$.

Dengan demikian hasil prasiklus melalui dua tabel di atas peserta didik belum sepenuhnya mencapai KKM 75. Tabel skor menunjukkan jumlah hasil uji kompetensi anak 1950 dengan rat-rata kelas 65 nilai tertinggi 100 dan terendah 25, dari presentase hanya 17 peserta didik yang berhasil mencapai KKM. Interval menunjukkan nilai 25-38 ada 3 peserta didik, 39-35 ada 10 peserta didik, 53-66 tidak ada peserta didik 67-80 ada 13 peserta didik, 81-94 tidak ada peserta didik dan 95-100 ada 4 peserta didik.

Dari deskripsi di atas dapat disimpulkan bahwa hasil peserta didik mendapat skor di bawah KKM ada 13 peserta didik. Berdasarkan nilai rata-rata dapat disimpulkan bahawa pesrta didik belum 100\% memahami materi. Pada tanggal 10 Agustus 2018, terdapat hasil skor peserta didik pada siklus 2 yang hasilnya memuaskan peneliti, dari hasil evaluasi yang diperoleh dari 
keseluruhan adalah 2640 dengan rata-rata 88 dengan rincian nilai tertinggi 100 dan nilai terendah 60 .

Dari data di atas dapat dibuat interval sebagai berikut:

a. Tentukan rentang, ialah data terbesar di kurang data terkecil. Dalam prasiklus data terbesar adalah 100 dan data terkecil 60, maka rentangnya adalah $100-60=40$

b. Tentukan banyak kelas interval yang diperlukan. Untuk menentukan banyaknya kelas interval dapat digunakan aturan sturges yaitu:

$=1+3,3 \log n$

$=1+3,3 \log 30$

$=1+3,3(1,48)$

$=1+4,78$

$=5,78$

Jadi banyaknya kelas interval yang dapat dibulatkan menjadi 6

c. Menentukan panjang kelas interval (p)

$$
\begin{aligned}
& P=\frac{\text { Rentang }}{\text { banyak kelas }} \\
= & 40: 6 \\
= & 6,7
\end{aligned}
$$

Jadi dari hasil diperoleh 6,7 dibulatkan menjadi 7 sebagai kelas. Interval.

Dari data di atas dapat diketahui jumlah peserta didik yang berada direntang nilai $60-67$ ada 3 peserta didik, 68-75 tidak ada peserta didik, 76-83 ada 12 peserta didik, 84-92 tidak ada peserta didik dan 93-100 ada 15 peserta didik. Dari pengamatan peneliti terhadap hasil dari 30 peserta didik, ada 28 peserta didik yang dapat menjawab yaitu $93 \%$ sedangkan yang tidak dapat menjawab ada 2 peerta didik yaitu beberapa yang bisa menjawab $7 \%$.

Dengan demikian hasil siklus 2 peserta didik hampir sepenuhnya mencapai KKM 75 hanya ada 3 peserta didik yang masih 
di bawah KKM. Tabel skor menunjukkan jumlah hasil uji kompetensi anak 2640 dengan rat-rata kelas 88 nilai tertinggi 100 dan terendah 60, dari presentase ada 27 peserta didik yang berhasil mencapai KKM. Interval menunjukkan 60-67 ada 3 peserta didik, 76-83 ada 12 peserta didik, dan 93-100 ada 15 peserta didik.

Dari deskripsi di atas dapat disimpulkan bahwa hasil peserta didik mendapat skor sesuai KKM ada 27 peserta didik. Berdasarkan nilai rata-rata dapat disimpulkan bahawa pesrta didik sudah $90 \%$ memahami materi.

\section{B. Pembahasan Hasil Penelitian Perbaikan Pembelajaran}

Hasil pembelajaran prasiklus dengan menggunakan metode ceramah, tanya jawab dan tugas dengan menggunakan media pembelajaran menggunakan spidol dan papan tulis setelah dievaluasi, dengan nilai KKM 70 di dapat data sebagai berikut nilai dari keseluruhan adalah 1725, dengan rincian nilai tertinggi 100 ada 4 peserta didik, dan yang mendapat nilai 75 ada 8 peserta didik, sedangkan yang mendapat nilai 50 ada 11 peserta didik, dan yang mendapat 25 ada 7 peserta didik.

Nilai hasil evaluasi peserta didik tidak memuaskan, masih ada 18 peserta didik atau 60\% yang di bawah KKM atau tidak tuntas, dan ada 12 peserta didik atau $40 \%$ yang di atas KKM atau tuntas dari 30 peserta didik yang terdiri dari 14 orang laki-laki dan 16 orang perempuan. Dari pengamatan peneliti terhadap hasil dari 30 peserta didik, hanya 8 peserta didik yang dapat menjawab yaitu 27\%, sedangkan yang tidak dapat menjawab ada 22 peerta didik yaitu beberapa yang bisa menjawab $73 \%$. Penyebab rendahnya hasil belajar peserta didik kelas IV B dalam pelajaran Matematika materi KPK dan FPB di SD Muhammadiyah 01 Depok dapat ditemukan sebagai berikut:

1. Penjelasan materi kurang menarik. Penggunaan ceramah dan tanya jawab mengakibatkan peserta didik kesulitan dalam memberikan gambaran dalam ranah pemahamannya mengenai KPK dan FPB. 
2. Dominasi guru sehingga peserta didik cendrung pasif dalam belajar mengakibatkan peserta didik yang mengalami kesulitan belajar cendrung tidak dapat memahami materi dengan baik.

3. Pembelajaran masih bersifat individual sehingga tingkat keberhasilan atau ketuntasan secara klasikal sangat rendah. Pembelajaran konvensional mengakibatkan setiap individu peserta didik bekerja dan bertanggung jawab terhadap hasil pekerjaannya sendiri, sehingga bagi peserta didik yang belum memahami akan kesulitan untuk menyelesaikan tugasnya karena tidak adanya wadah berupa tugas atau bentuk kerjasama yang memungkinkan terjadinya pertukaran ide, gagasan, atau pengetahuan di antara sesama peserta didik

Pada siklus 1 yang hasilnya masih kurang memuaskan, dari seluruh peserta didik yang ada di kelas 4b. dari hasil evaluasi yang diperoleh dari keseluruhan adalah 1950 dengan rata-rata 65 dengan rincian nilai tertinggi 100 terendan 25, skor siklus 1 yang tuntas 17 (57\%) dan tidak tuntas ada 13 (43\%). Dari pengamatan peneliti dari 30 peserta didik, hanya 19 peserta didik yang dapat menjawab yaitu 63\% sedangkan yang tidak dapat menjawab ada 11 peerta didik yaitu beberapa yang bisa menjawab $37 \%$. Maka dari hasil pengamatan dari siklus 1 yang tidak menaikan nilai rat-rata peserta ini maka peneliti meneruskan ke siklus 2.

Pada siklus 2 peneliti melakukan beberapa tindakan antara lain:

1. Menggunakan metode pembelajaran yang bervariasi dan efektif yang sesuai secara maksimal sehingga peserta didik tidak mengalami kesulitan dan hasil belajar dapat diperoleh secara maksimal.

2. Menggunakan media pembelajaran yang sesuai secara maksimal sehingga terciptanya suasana pembelajaran yang kondusif, dan menyenangkan bagi peserta didik.

3. Guru harus memberikan kesempatan kepada peserta didik untuk bertanya dan melibatkan peserta didik dalam materi.

Pada siklus 2 yang hasilnya memuaskan peneliti, dari hasil evaluasi yang diperoleh dari keseluruhan adalah 2640 dan rat-rata kelas 88 dengan 
rincian nilai tertinggi 100 dan terendah 60, dari nilai tertinggi ada 27( 90\%) peserta didik dan nilai terendah ada $3(10 \%)$. Dan dari pengamatan peneliti terhadap hasil dari 30 peserta didik, ada 28 peserta didik yang dapat menjawab yaitu $93 \%$ sedangkan yang tidak dapat menjawab ada 2 peerta didik yaitu beberapa yang bisa menjawab 7\%. sehingga mengalami peningkatan.

Dengan demikian metode tangga dengan menggunakan media konkrit dapat meningkatkan hasil belajar peserta didik dalam perhatian, bersimulasi, meningkatkan kemampuan bersosialisasi dan berkomunikasi pesrta didik serta lebih kooperatif.dan dapat meningkatkan kualitas hasil belajar peserta didik dalam nilai matematika.

\section{KESIMPULAN DAN SARAN TINDAK LANJUT}

\section{A. Kesimpulan}

Berdasarkan hasil penelitian PTK dan pembahasan yang telah diuraikan maka diperoleh kesimpulan bahwa penerapan metode tangga dengan menggunakan media konkrit dapat meningkatkan hasil belajar peserta didik kelas 4B SD Muhammadiyah 01 Depok pada mata pelajaran matematika materi KPK dan FPB. Hal ini dibuktikan dengan peningkatan persentase ketuntasan peserta didik disetiap siklusnya hingga mencapai kriteria keberhasilan tindakan yang telah ditentukan maka, penulis menarik kesimpuan, sebagai berikut:

1. Pada pembelajaran prasiklus dengan KKM 70 diperoleh rerata kelas 57,5. Peserta didik yang tuntas hanya 12 (40\%) dan dapat menjawab $3(10 \%)$ sedangkan yang tidak dapat menjawab ada 27 (90\%). Pada siklus 1 hasil rata-rata adalah 65. Yang tuntas sebanyak 17 orang (57\%) dan hasil pengamatan hanya 19 (63\%) dapat menjawab sedangkan yang tidak dapat menjawab ada $11(37 \%)$. Pada siklus 2 nilai rata-rata kelas kelas sebesar. Peserta didik yang tuntas dalam belajar sebanyak 27 (90\%), sedangkan hasil pengamatan didapat 28(93\%) yang dapat menjawab dan yang tidak 
dapat menjawab ada 2 (7\%). ini berarti jumlah peserta didik yang tuntas secara keseluruhan telah mencapai kriteria keberhasilan yang ditetapkan.

2. Metode tangga dapat meningkatkan hasil belajar peserta didik sampai 93\% pada siklus 2. Pola belajar dan karakteristik peserta didik yang aktif dan kreatif dapat dipahami oleh guru.

3. Dengan metode tangga dan media konkrit yang digunakan guru untuk menunjang pelajaran dapat meningkatkan nilaipeserta didik hingga mamp mencapai KKM, dan guru dapat mengembangkan metode-metode baru sehingga peserta didik tidak mengalami kejenuhan.

\section{B. Saran Tindak Lanjut}

Berdasarkan pada kesimpulan di atas ada beberapa hal yang sebaiknya dilakukan dalam upaya meningkatkan kualitas pembelajaran.

\section{Saran Peneliti}

a. Guru hendaknya menerapkan metode metode tangga dengan menggunakan media konkrit dalam pembelajaran matematika sebagai salah satu alternatif untuk meningkatkan hasil belajar peserta didik terutama untuk materi yang berkaitan dengan kemampuan menulis peserta didik.

b. Penerapan metode tangga dengan menggunakan media konkrit yang digunakan serta sesuai dengan materi pembelajaran yang diberikan perlu mendapat perhatian yang serius sebelum dalam merancang suatu rencana pembelajaran. Hal ini bertujuan untuk memberikan hasil yang lebih optimal atas seluruh proses pembelajaran yang dilakukan.

c. Penelitian ini diharapkan untuk memperkaya wawasan dalam mengembangkan pengetahuannya dimasa yang akan datang dan diharapkan menjadi suatu masukan yang dapat dikembangkan menjadi sebuah model pembinaan dalam proses pembelajaran untuk meningkatkan hasil belajar lebih lanjut

d. Perbaikan pembelajaran harus dilakukan, agar menjadi masukan bagi sekolah. 
e. Hasil penelitian ini diharapkan dapat memberi sumbangan nyata terhadap upaya memecahkan masalah bersama dalam rangka meningkatkan mutu pendidikan.

\section{Peneliti lebih lanjut}

a. Sebagai seorang pendidik yang telah melakukan PTK, penulis PTK ini mempunyai banyak manfaat dalam dunia keguruan.

b. Diharapkan para pendidik dapat menggunakan metode-metode yang bervariasi dalam mengajar, seperti yang penulis lakukan metode tangga sehingga kegiatan belajar mengajar lebih bervariasi dan meningkat minat peserta didik dalam belajar.

c. PTK yang penulis buat berguna sebagai peningkatan profesional guru, dan penulis dapat membantu guru-guru yang mengalami kesulitan dikelasnya.

\section{DAFTAR PUSTAKA}

Anita W, Sri dkk. (2017). Strategi Pembelajaran di SD. Banten: Universitas Terbuka.

AZ, Mulyana. (2001). Rahasia Matematika. Surabaya : Edutama Mulia Sumanto.

Badar, Dadan Samsul dan Sulfemi, Wahyu Bagja. (2014). Pengaruh Rasa Percaya Diri dan Motivasi Berprestasi Terhadap Kinerja di Kecamatan Ciampea Kabupaten Bogor. Edutecno. 10 (1), 1-10,

Djamarah, Syaiful Bahri, dan Aswan Zain. (2010). Strategi Belajar Mengajar. Jakarta: Rineka Cipta.

Fajartriani, Tia dan Sulfemi, Wahyu Bagja. (2014). Pengaruh Motivasi Kerja Guru dan Iklim Organisasi Terhadap Kinerja Guru SMA Negeri di Kecamatan Cigudeg. Edutecno. 8 (1), 17-26

Hartono, Rudi. (2013). Ragam Model Mengajar yang Mudah Diterima Murid. Jogjaarta: Diva Press.

Hamalik,. Oemar. (2011). Kurikulum dan Pembelajaran. Jakarta: PT Bumi Aksara.

Hermawan, Asep Herry, Novi Resmini dan Andayani. (2017). Pembelajaran Terpadu di SD. Tangerang Selatan: Universitas Terbuka.

Ibrahim, R, dan Syoudih, Nana. (2003). Perencanaan Pengajaran. Jakarta: PT. Rinika Cipta.

Jennah, Rodhatul. (2009). Media Pembelajaran. Banjarmasin : Antasari Press. 
Masriyah dan Rahayu, Endah Budi. (2007). Evaluasi Pembelajaran Matematika. Jakarta: Departemen Pendidikan Nasional Universitas Terbuka.

Muhsetyo, Gatot dkk. (2008). Pembelajaran Matematika SD. Jakarta: Universitas Terbuka..

Munadi, Yudhi. (2012). Media Pembelajaran Sebuah Pendekatan Baru. Jakarta.Gaung Prersada Press.

Sanjaya, Wina. (2008). Strategi Pembelajaran Berorientasi Standar Proses Pendidikan. Jakarta: Kencana Prenada Media.

Sudjana, Nana. (2004) Dasar-Dasar Proses Mengajar. Bandung: Sinar Baru Algensido Offeset,.

Sumantri M. Dan Syaodih, N (2006). Perkembangan Peserta Didik. Jakarta: Universitas Terbuka.

Suwangsih, E, \& Triurlina. (2010). Model Pembelajaran Matematika. Bandung: UPI Press.

Suryanto, Adi, dkk. (2017). Evaluasi Pembelajaran di SD. Tangerang Selatan: Universitas Terbuka.

Sulfemi, Wahyu Bagja. (2013). Pengaruh Persepsi Siswa atas Kemampuan Pedagogik Guru dan Motivasi Belajar Siswa Terhadap Prestasi Belajar Ilmu Pengetahuan Sosial Siswa (Survei di SMK Swasta Kabupaten Bogor). Edutecno. 7 (2), 17-26.

Sulfemi, Wahyu Bagja. (2014). Pengaruh Motivasi dan Lingkungan Sekolah Terhadap Prestasi Belajar Sejarah Di SMA Negeri Leuwilang Kabupaten Bogor. Fascho : Kajian Pendidikan dan Sosial Kemasyarakatan 9 (2), 42-52.

Sulfemi, Wahyu Bagja. (2015). Kemampuan Pedagogik Guru. Prosiding Seminar Nasional. STKIP Muhammadiyah Bogor 1. (1). 71-83

Sulfemi, Wahyu Bagja. (2015). Challenges Of Indonesian Teacher Competence in dealing with Asean Economic Cummunity (AEC). Engglis Forum. $1(1), 69-79$

Sulfemi, Wahyu Bagja. (2015). Pengaruh Metode Pembelajaran Kontekstual dan Penggunaan Media Video Pendidikan Terhadap Hasil Belajar IPS.

Sulfemi, Wahyu Bagja. (2016). Hubungan Persepsi Peserta Didik Tentang Kompetensi Guru Mata Pelajaran Sejarah dengan Hasil Belajar Mata Pelajaran Sejarah di Kelas X SMA Negeri 1 Pamijahan Kabupaten Bogor. Fascho, 5 (2), 52-70.Edutecno 13 (2), 1-10

Sulfemi, Wahyu Bagja. (2016). Kompetensi Profesionalisme Guru Indonesia dalam Menghadapi MEA. Prosiding Seminar Nasional STKIP Muhammadiyah Bogor. 1 (1), 62-77 
Sulfemi, Wahyu Bagja. (2016). Hubungan antara Persepsi Guru pada Kepemimpian Kepala Sekolah dan Motivasi Guru dengan Kinerja guru dalam Proses Pembelajaran di SMA Negeri 1 Ciomas. Fascho : Kajian Pendidikan dan Sosial Kemasyarakatan, 5 (1), 36-55

Sulfemi, Wahyu Bagja. (2016). Perundang-Undangan Pendidikan. Bogor : Program Studi Administrasi Pendidikan STKIP Muhammadiyah Bogor

Sulfemi, Wahyu Bagja dan Lestari, Ayu Hopilatul. (2017). Korelasi Kompetensi Pedagogik Guru dengan Prestasi Belajar Mata Pelajaran IPS Di SMP Muhammadiyah Pamijahan Kabupaten Bogor. Edutecno. 16 (1), 1-16

Sulfemi, Wahyu Bagja dan Abdul Qodir. (2017). Hubungan Kurikulum 2013 Dengan Motivasi Belajar Peserta Didik Di SMK Pelita Ciampea. Edutecno 17 (2), 1-8.

Sulfemi, Wahyu Bagja. (2017). Analisis Pengaruh Motivasi Dan Disiplin Terhadap Kinerja Guru (Studi Kasus di SMA Negeri 1 Pamijahan Kabupaten Kabupaten Bogor). Prosiding Seminar Nasonal STKIP Muhammadiyah Bogor. 1 (1), 342-357

Sulfemi, Wahyu Bagja dan Supriyadi, Dede. (2018). Pengaruh Kemampuan Pedagogik Guru dengan Hasil Belajar IPS. Edutecno 17 (1), 1-10.

Wardhani, IGAK dan Kuswaya Wihardit. (2017). Penelitian Tindakan Kelas. Banten: Universitas Terbuka. 